\title{
PENGARUH STRES DAN MOTIVASI TERHADAP PRODUKTIVITAS KERJA KARYAWAN PADA PT EPSON BATAM
}

\author{
Kintan Benvia Cherny, Dwi Kartikasari \\ Prodi Administrasi Bisnis Terapan, Politeknik Negeri Batam, 29461 \\ *Corresponding author. Tel/HP: 08992071222 \\ Email: kintansb.archery@gmail.com
}

\begin{abstract}
ABSTRAK
Penelitian ini bertujuan mengetahui pengaruh stres kerja dan motivasi kerja terhadap produktivitas kerja karyawan di PT Epson Batam. Penelitian ini menggunakan motode explanatory research Sampel yang diambil sebanyak 100 orang Karyawan di Dept. General Office (GO). Penarikan sampel dilakukan hanya pada bagian Dept. Go tidak menyeluruh dari bagian populasi (area sampling). Pengumpulan data dilakukan dengan penyebaran kuisioner. Data dianalisis dengan analisis regresi berganda melalui program SPSS 20. Hasil penelitian ini menunjukkan bahwa stres kerja dan motivasi kerja secara simultan berpengaruh positif dan signifikan terhadap produktivitas kerja karyawan. Namun secara parsial stres kerja tidak memiliki pengaruh yang positif dan signifikan terhadap produktivitas kerja, tetapi motivasi kerja secara parsial berpengaruh positif dan signifikan terhadap produktivitas kerja.
\end{abstract}

Kata Kunci: Stres, Motivasi, Produktivitas Kerja

\begin{abstract}
The purpose of this study is to determine the effect of stress at work and working motivation on the productivity at the PT Epson Batam. This study had used Explanatory research as main method and Area Sampling as sampling method. Sample were taken as a part from the population that is one hundred employees. Data were taken by using list of question. Data were analyzed by using Regression Method and through SPSS 20. The result of the study have shown that stress at work and working motivation significantly influence the employee's working productivity.
\end{abstract}

Keyword: Stress, Motivation, Work Productivity

\section{Pendahuluan}

Sumber Daya Manusia (SDM) merupakan faktor terpenting dalam setiap kegiatan sebuah perusahaan, karena bagaimanapun canggihnya teknologi yang digunakan tanpa didukung oleh manusia sebagai pelaksana, kegiatan operasional tidak akan mampu menghasilkan output yang diharapkan. Manusia sebagai makhluk sosial juga mempunyai pemikiran dan keinginan yang berbeda-beda, sedangkan perusahaan mengharapkan karyawannya dapat bekerja dengan baik dan memiliki produktivitas yang tinggi, serta mampu menjabarkan visi 
dan misi yang telah disepakati bersama dalam rangka pencapaian tujuan perusahaan.

Peran sumber daya manusia yang semula hanya sebagai penunjang perlu diubah menjadi strategik, dimana pengelolaan sumber daya manusia ditujukan agar organisasi dapat beroperasi dengan efisien sehingga dapat mencapai sasaran kerjanya. Untuk mendapatkan sumber daya manusia yang diharapkan oleh organisasi agar memberikan andil positif terhadap semua kegiatan perusahaan, setiap karyawan diharapkan memiliki motivasi kerja yang tinggi sehingga nantinya akan meningkatkan produktivitas kerja. Motivasi merupakan hal yang sangat penting untuk diperhatikan oleh pihak manajemen bila mereka menginginkan setiap karyawan dapat memberikan kontribusi positif terhadap pencapaian tujuan perusahaan. Karena dengan motivasi, seorang karyawan akan memiliki semangat yang tinggi dalam melaksanakan tugas yang dibebankan kepadanya. (Guay et al, 2010) Menyatakan bahwa motivasi adalah sesuatu yang mengacu pada alasan yang mendasari perilaku. Sopiah $(2008: 170)$ menyampaikan bahwa motivasi adalah keadaan dimana usaha dan kemampuan keras seseorang diarahkan kepada pencapaian hasil-hasil atau tujuan tertentu. Hasil-hasil yang dimaksud bisa berupa produktivitas, kehadiran atau perilaku kerja kreatif lainnya. Menurut Malayu S.P Hasibuan (2006: 219) bahwa motivasi adalah pemberian daya pengerak yang menciptakan kegairahan kerja seseorang, agar mereka mau bekerja sama, bekerja efektif dan terintegrasi dengan segala daya upayanya untuk mencapai kepuasan.

\section{Tujuan Penelitian}

Tujuan penelitian yang dilakukan pada PT Epson sebagai berikut:
1. Untuk mengetahui apakah stres berpengaruh terhadap produktivitas kerja karyawan

2. Untuk mengetahui apakah motivasi kerja berpengaruh terhadap produktivitas kerja karyawan

3. Untuk mengetahui apakah stres kerja dan motivasi kerja secara simultan berpengaruh terhadap produktivitas kerja karyawan

\section{Kajian Pustaka \\ 1. Stres}

Stres merupakan hal yang lumrah dialami oleh setiap individu yang diakibatkan oleh faktor dari dalam maupun dari luar diri manusia itu sendiri. Stres bersifat fluktuasi kadang naik kadang turun tergantung dengan kondisi kerja yang dialami. Badeni (2013) stres adalah ketegangan atau tekanan emosional yang dialami seseorang yang sedang menghadapi tuntutan yang sangat besar atau kesempatan melakukan sebuah kegiatan penting, yang dalam pemenuhannya terdapat hambatan-hambatan dan ketidakpastian yang dapat mempengaruhi emosi, pikiran dan kondisi fisik seseorang.

Stres merupakan reaksi fisik terhadap permasalahan kehidupan yang dialaminya dan apabila fungsi organ tubuh sampai terganggu dinamakan distress. Sedangkan depresi merupakan reaksi kejiwaan terhadap stressor yang dialaminya. Stres kerja adalah suatu bentuk tanggapan seseorang, baik fisik maupun mental terhadap suatu perubahan di lingkungannya yang dirasakan mengganggu dan mengakibatkan dirinya terancam, (Panji Anoraga 2001, h.108).

\section{Motivasi}

Guay, et al, menyatakan bahwa motivasi adalah sesuatu yang mengacu pada alasan yang mendasari perilaku. Penulis menyimpulkan secara umum motivasi merupakan suatu perilaku yang terjadi karena alasan ataupun dorongan tertentu untuk mencapai sesuatu. Motivasi berkaitan dengan kekuatan, arah perilaku dan faktor- 
faktor yang mempengaruhi seseorang berperilaku dengan cara tertentu.

\section{Produktivitas}

Secara filosofi produktivitas merupakan sikap mental yang selalu berusaha dan mempunyai pandangan bahwa suatu kehidupan hari ini lebih baik dari hari kemarin dan hari esok lebih baik dari hari ini. Secara teknis produktivitas merupakan perbandingan antara hasil yang dicapai dan keseluruhan sumber daya yang dipergunakan. Malayu S.P Hasibuan (2005: 127) mengungkapkan bahwa secara lebih sederhana maksud dari produktivitas adalah perbandingan secara ilmu hitung antara jumlah yang dihasilkan dan jumlah setiap sumber yang dipergunakan selama produksi berlangsung. Konsep produktivitas pada dasarnya dapat dilihat dari dua dimensi, yaitu dimensi individu dan dimensi organisasi. Pengkajian masalah produktivitas dari dimensi individu tidak lain melihat produktivitas terutama dalam hubungannya dengan karakteristikkarakteristik kepribadian individu.

\section{Kerangka Pemikiran}

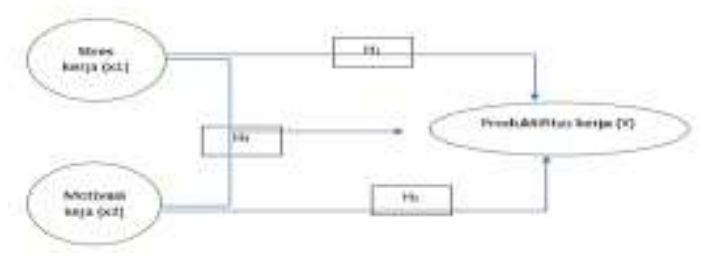

H1 : Stres kerja (X1) berpengaruh terhadap produktivitas kerja karyawan

H2 : Motivasi kerja (X2) berpengaruh terhadap produktivitas kerja karyawan

H3 : Stres kerja dan Motivasi kerja (X3) berpengaruh terhadap produktivitas kerja karyawan.
METODE

1. Rancangan Penelitian

Penelitian ini menggunakan metode eksplanatory research. Menurut Asep Hermawan (2009), "Explanatory research merupakan penelitian yang menjelaskan hubungan kausal antara variabel-variabel melalui pengujian hipotesis". Maksudnya adalah penelitian ini menjelaskan pengaruh antara Stres dan Motivasi terhadap Produktivitas Kerja pada PT Epson Batam.

\section{Populasi dan Sampel}

\section{a. Populasi}

Menurut Sugiyono (2008) "Populasi adalah wilayah generalisasi terdiri atas obyek/subyek yang mempunyai kualitas dan karakteristik tertentu. ditetapkan oleh peneliti untuk dipelajari dan kemudian ditarik kesimpulan". Dalam penelitian ini populasinya adalah staff yang berada di departemen (GO General Office) yang berjumlah 100 orang pada PT Epson Batam

\section{b. Sampel}

Menurut Sugiyono (2008) "sampel adalah sebagian dari jumlah dan karakteristik yang dimiliki oleh populasi tersebut". Sampel penelitian ini adalah seluruh populasi penelitian. Menurut Sugiyono (2008), jika penelitian menggunakan seluruh elemen populasi menjadi data penelitian, maka disebut sensus. Pada penelitian ini metode pengambilan sampel yang digunakan adalah sensus, dengan jumlah 100 responden dari departemen GO (General Office).

\section{Validitas dan Reliabilitas}

\section{a. Uji Validitas}

Validitas adalah suatu ukuran yang menunjukkan tingkat kevalidan atau kesahihan suatu instrumen. Uji validitas digunakan untuk mengukur sah atau valid tidaknya suatu kuesioner. Suatu kuesioner dikatakan valid jika pertanyaan pada kuesioner mampu untuk mengungkapkan sesuatu yang akan diukur oleh kuesioner 
tersebut. Uji signifikansi dilakukan dengan cara membandingkan nilai $r$ hitung dengan $r$ tabel untuk degree of freedom $(\mathrm{df})=\mathrm{n}-2$, dalam hal ini $\mathrm{n}$ adalah jumlah sampel.Untuk menguji apakah masing masing indikator valid atau tidak, dapat dilihat dalam tampilan output Cronbach alpha pada kolom correlated item-total correlation. Jika $\mathrm{r}$ tabel dan nilai.

\section{b. Uji Reliabilitas}

Reliabilitas instrumen menggambarkan pada kemantapan dan kekuatan alat ukur yang digunakan. Suatu alat ukur dikatakan memiliki reliabilitas atau kekuatan yang tinggi atau dapat dipercaya apabila alat ukur tersebut stabil sehingga dapat diandalkan dan dapat digunakan untuk meramalkan. Uji reliabilitas dilakukan dengan menghitung cronbach alpha dari masing-masing instrumen dalam setiap variabel. Suatu konstruk atau variabel dikatakan reliabel jika memberikan nilai Cronbach Alpha > 0,60 (Ghozali) 2006.

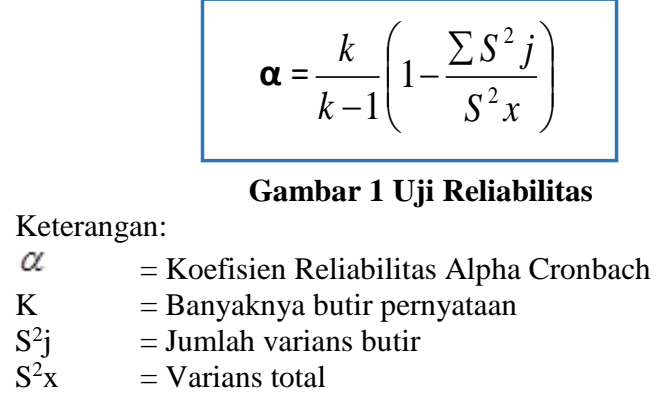

\section{Analisis Data}

\section{a. Analisis Statistik Deskriptif}

Analisis statistik deskriptif adalah suatu analisis yang dilakukan untuk memberikan gambaran secara umum terhadap obyek yang diteliti melalui data sampel atau populasi yang diteliti.

a. Menghitung Mean

$$
\bar{x}=\frac{x_{1}+x_{2}+\ldots+x_{n}}{n}
$$

$$
\begin{array}{ll} 
& \text { Keterangan : } \\
\bar{x} & =\text { rata-rata } \\
\mathrm{n} & =\text { banyak data }
\end{array}
$$

\section{Gambar 2 Rumus Mean}

\section{b. Analisis Statistik Inferensial}

Analisis statistik inferensial Menurut (Sugiyono, 2008) statistik inferensial adalah teknik statistik yang digunakan untuk menganalisis data sampel dan hasilnya diberlakukan untuk populasi. Penelitian ini menggunakan analisis regresi berganda yang dibantu oleh SPSS 20. sebelum dilakukan analisis regresi, dilakukan uji asumsi klasik terlebih dahulu.

\section{c. Uji Asumsi Klasik}

Uji asumsi klasik ini digunakan untuk memperoleh nilai/hasil yang tidak bias atau estimator linear tidak bias yang terbaik, maka model regresi harus memenuhi beberapa asumsi. Adapun asumsi-asumsi yang dimaksud adalah:

\section{Uji Normalitas}

Uji normalitas bertujuan untuk menguji salah satu asumsi dasar analisis regresi berganda, yaitu variabel-variabel independen dan dependen harus berdistribusi normal atau mendekati normal (Ghozali) 2006. Uji statistik sederhana yang sering digunakan untuk menguji asumsi normalitas adalah dengan menggunakan uji normalitas dari Kolmogorov Smirnov. Metode pengujian normal tidaknya distribusi data dilakukan dengan melihat nilai signifikansi variabel, jika signifikan lebih besar dari alpha $10 \% \quad(0.1)$, maka menunjukkan distribusi data normal.

\section{Multikolinearitas}

Uji multikolinieritas bertujuan untuk menguji apakah dalam model regresi ditemukan adanya korelasi antar variabel bebas (independen). Model regresi yang baik seharusnya tidak terjadi korelasi di 
antara variable independen. Suatu model regresi dikatakan bebas dari multikolinieritas apabila nilai tolerance > 0,1 (Ghozali) 2006. Untuk mendeteksi gejala multicolinearity, peneliti menggunakan koefisien korelasi. Koefisien korelasi sebesar 1 antar variabel independen yang terdapat pada model regresi menunjukan adanya hubungan yang sempurna atau mendekat sempurna. Hal ini mengindikasikan terdapat adanya multikolineraritas dalam model regresi yang dihasilkan.

\section{Heteroskedastisitas}

Uji heterokedastisitas dilakukan untuk menguji apakah dalam sebuah model regresi, terjadi ketidaksamaan varians dari residual dari satu pengamatan ke pengamatan yang lain. Jika varians dari residul dari satu pengamatan ke pengamatan yang lain tetap, maka disebut homokedastisitas. Dan jika varians berbeda, disebut heterokedastisitas. Model regresi yang baik adalah tidak terjadi heteroskedastisitas (Ghozali) 2006. Salah satu cara untuk melihat ada tidaknya heterokedaskitas adalah menggunakan uji Glejser. Uji ini dilakukan dengan cara melakukan regresi variabel bebas dengan nilai absolut dari residualnya. Jika variabel bebas signifikan secara statistik mempengaruhi variabel dependen, maka ada indikasi terjadi heterokedaskitas. Sebaliknya, jika variabel bebas tidak signifikan secara statistik mempengaruhi variabel dependen, maka ada indikasi tidak terjadi heterokedaskitas (Ghozali) 2006.

\section{Uji Hipotesis}

\section{a. Uji t (Signifikan Parsial)}

Uji t digunakan untuk menguji signifikansi hubungan antara variabel $\mathrm{X}$ dan $\mathrm{Y}$, apakah variabel stress (X1) dan motivasi (X2) benar-benar berpengaruh terhadap variabel produktivitas kerja (Y) secara terpisah atau parsial Ghozali (2006). Adapun hipotesis yang digunakan dalam pengujian ini adalah:
Ho : Variabel-variabel bebas yaitu stres (X1) dan motivasi (X2) tidak mempunyai pengaruh yang signifikan terhadap variabel terikatnya yaitu produktivitas kerja (Y).

Ha : Variabel-variabel bebas yaitu stres (X1) dan motivasi (X2) mempunyai pengaruh yang signifikan terhadap variabel terikatnya yaitu produktivitas kerja (Y).

Dasar pengambilan keputusan Ghozali (2006) adalah dengan menggunakan angka probabilitas signifikansi, yaitu:

a. Apabila angka probabilitas signifikansi $>0.1$ maka Ho diterima dan Ha ditolak.

b. Apabila angka probabilitas signifikansi < 0.1 maka Ho ditolak dan $\mathrm{Ha}$ diterima.

\section{b. Uji F (Uji Simultan)}

Dalam penelitian ini, uji $F$ digunakan untuk mengetahui tingkat signifikansi pengaruh variabel-variabel independen secara bersama-sama (simultan) terhadap variabel dependen (Ghozali) 2006. Dalam penelitian uji $F$ digunakan untuk membuktikan hipotesis apakah variabel Metode Pelatihan berpengaruh bersamasama (simultan) terhadap kompetensi karyawan. Adapun hipotesis yang digunakan adalah:

Ho : Variabel-variabel bebas yaitu stres (X1) dan motivasi (X2) tidak mempunyai pengaruh yang signifikan secara bersama-sama terhadap variabel terikatnya yaitu produktivitas kerja (Y).

Ha : Variabel-variabel bebas yaitu stres (X1) dan motivasi (X2) mempunyai pengaruh yang signifikan secara bersama-sama terhadap variabel terikatnya yaitu produktivitas kerja (Y). 
Dasar pengambilan keputusan Ghozali (2006) adalah dengan menggunakan angka probabilitas signifikansi, yaitu:

a. Apabila angka probabilitas signifikansi > 0.1 maka Ho diterima dan Ha ditolak.

b. Apabila angka probabilitas signifikansi $<0.1$ maka Ho ditolak dan $\mathrm{Ha}$ diterima.

\section{HASIL PENELITIAN DAN PEMBAHASAN}

\section{Uji Validitas dan Reliabilitas}

\section{Tabel 1 Hasil Uji Validitas}

\begin{tabular}{|c|c|c|c|c|}
\hline \multirow{2}{*}{\begin{tabular}{|r|} 
Variabel \\
Stres $(\mathrm{X} 1)$
\end{tabular}} & \multicolumn{2}{|r|}{ Item } & \multirow{2}{*}{\begin{tabular}{|c}
$\begin{array}{c}\text { R Hitung/R } \\
\text { Probabilitas }\end{array}$ \\
0,547
\end{tabular}} & \multirow{2}{*}{$\begin{array}{l}\text { Keteran } \\
\text { gan } \\
\text { Valid }\end{array}$} \\
\hline & $\mathrm{X} 1.1$ & $\begin{array}{l}\text { Tuntutan tugas yang } \\
\text { memberatkan sering } \\
\text { membuat sava frustasi }\end{array}$ & & \\
\hline & $\mathrm{X} 1.2$ & $\begin{array}{l}\text { Dalam menjalankan } \\
\text { tugas sava ditekan } \\
\text { dengan banvak peraturan }\end{array}$ & 0,637 & Valid \\
\hline & $\mathrm{X} 1.3$ & $\begin{array}{l}\text { Kerja keras saya tidak } \\
\text { sebanding dengan } \\
\text { hasil/keuntungan yang } \\
\text { saya terima }\end{array}$ & 0,653 & Valid \\
\hline & $\mathrm{X} 1.4$ & $\begin{array}{l}\text { Pekerjaan dan tugas saya } \\
\text { terasa membosankan }\end{array}$ & 0,753 & Valid \\
\hline & $\mathrm{X} 1.5$ & $\begin{array}{l}\text { Tugas yang menantang } \\
\text { membuat saya tidak } \\
\text { bersemangat }\end{array}$ & 0,582 & Valid \\
\hline & $\mathrm{X} 1.6$ & $\begin{array}{l}\text { Pekerjaan yang saya } \\
\text { lakutkan memiliki resiko } \\
\text { yang sangat besar }\end{array}$ & 0,556 & Valid \\
\hline & $\mathrm{X} 1.7$ & $\begin{array}{l}\text { Prosedur kerja yang ada } \\
\text { di perusahaan } \\
\text { menghambat pencapaian } \\
\text { target keria sava }\end{array}$ & 0,654 & Valid \\
\hline & $\mathrm{X} 1.8$ & $\begin{array}{l}\text { Tugas pekeriaan yang } \\
\text { saya lakukan tidak } \\
\text { teeriadwal dengan baik }\end{array}$ & 0,626 & Valid \\
\hline & $\mathrm{X} 1.9$ & $\begin{array}{l}\text { Target perusahaan dan } \\
\text { tuntutan tugas terlalu } \\
\text { tinggi sehingga } \\
\text { memberatkan tugas- } \\
\text { tugas sava }\end{array}$ & 0,723 & Valid \\
\hline & $\mathrm{X} 1.10$ & $\begin{array}{l}\text { Tujuan yang telah } \\
\text { ditetapkan oleh } \\
\text { perusahaan tidak sesuai } \\
\text { dengan harapan sayal }\end{array}$ & 0,662 & Valid \\
\hline
\end{tabular}

\begin{tabular}{|c|c|c|c|c|}
\hline & $\mathrm{X} 1.11$ & $\begin{array}{l}\text { Di perusahaan ini } \\
\text { pekerjaan karyawan } \\
\text { tidak dikeordinasikan } \\
\text { dengan baik sehingga } \\
\text { mengahambat } \\
\text { pencapaian target }\end{array}$ & 0,616 & Valid \\
\hline & $\mathrm{X} 1.12$ & $\begin{array}{l}\text { Saya merasa putus asa } \\
\text { karena sudah lama } \\
\text { bekerja di perusahaan ini } \\
\text { tetapi tidak mengalami } \\
\text { peningkatan posisi }\end{array}$ & 0,395 & Valid \\
\hline & $\mathrm{X} 1.13$ & $\begin{array}{l}\text { Di perusahaan ini } \\
\text { segalanya harus } \\
\text { dimintakan persetujuan } \\
\text { atasan, sehingga tidak } \\
\text { ada kesempatan bagi } \\
\text { saya untuk berpatisipasi } \\
\text { dalam mencapai tujuan } \\
\text { organisasi }\end{array}$ & 0,391 & Valid \\
\hline \multirow[t]{6}{*}{ Motivasi (X2) } & $\mathrm{X} 2.1$ & $\begin{array}{l}\text { Tugas dan tanggung } \\
\text { jawab yang diberikan } \\
\text { sesuai dengan } \\
\text { pendidikan dan } \\
\text { kemampuan saya }\end{array}$ & 0,658 & Valid \\
\hline & $\mathrm{X} 2.2$ & $\begin{array}{l}\text { Bila ada tugas kerja } \\
\text { lembur, saya melakukan } \\
\text { pelorejaan tersebut } \\
\text { dengan sebaik-baiknya }\end{array}$ & 0,664 & Valid \\
\hline & $\mathrm{X} 2.3$ & $\begin{array}{l}\text { Tugas yang diberikan } \\
\text { atasan selalu selesai } \\
\text { tepat wahtu }\end{array}$ & 0,530 & Valid \\
\hline & $\mathrm{X} 2.4$ & $\begin{array}{l}\text { saya dapat } \\
\text { menyelesaikan tugas } \\
\text { tanpa kendiala setiap hari }\end{array}$ & 0,687 & Valid \\
\hline & $\mathrm{X} 2.5$ & $\begin{array}{l}\text { Pekerjaan yang } \\
\text { dilaksanalkan sesuai } \\
\text { dengan yang telah } \\
\text { dijadwalkan }\end{array}$ & 0,730 & Valid \\
\hline & $\mathrm{X} 2.6$ & $\begin{array}{l}\text { Saya sering tidak } \\
\text { mencapai target } \\
\text { produlksi/pekeriaan }\end{array}$ & 0,604 & Valid \\
\hline
\end{tabular}

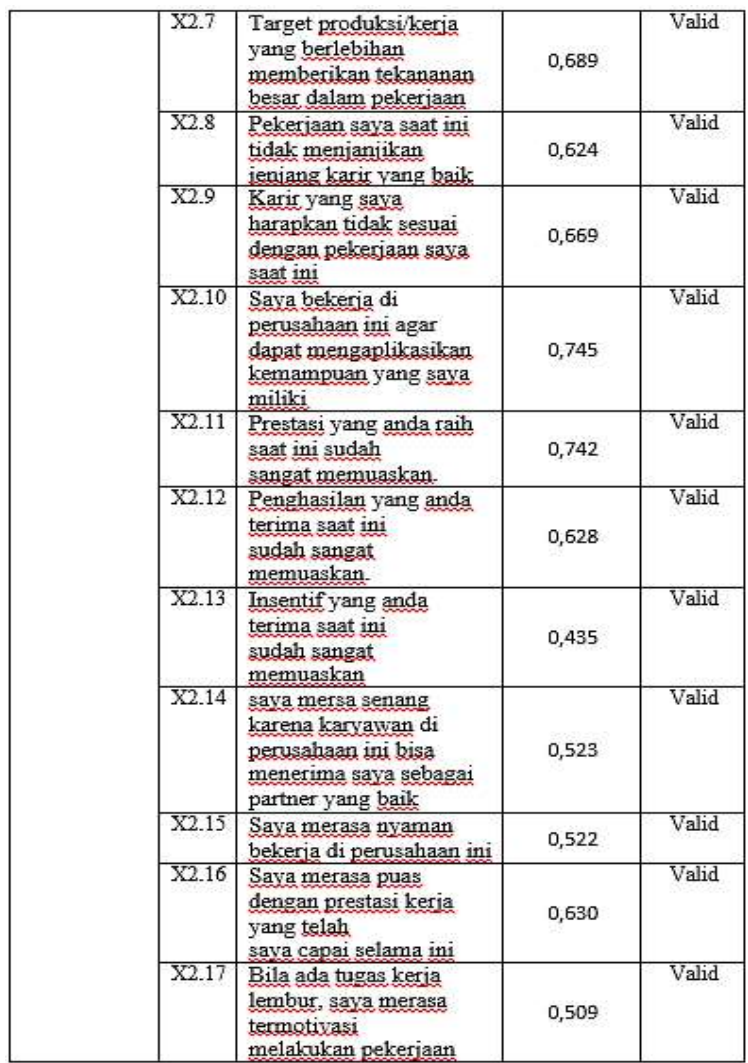




\begin{tabular}{|c|c|c|c|}
\hline & $\begin{array}{l}\text { tersebut dengan sebaik- } \\
\text { baiknya }\end{array}$ & & \\
\hline $\mathrm{X} 2.18$ & $\begin{array}{l}\text { Saya selalu mendapat } \\
\text { kesempatan ilut } \\
\text { berpartisipasi } \\
\text { dalam menentukan } \\
\text { tujuan yang ingin } \\
\text { dicapai oleh } \\
\text { atasan }\end{array}$ & 0,600 & Valid \\
\hline X2.19 & $\begin{array}{l}\text { saya merasa kebutuhan } \\
\text { dasar seperti untuk dapat } \\
\text { makan sudah ternenuhi }\end{array}$ & 0,674 & Valid \\
\hline $\mathrm{X} 2.20$ & $\begin{array}{l}\text { saya merasa dengan } \\
\text { bekerja di perusahaan } \\
\text { ini, kebutuhan } \\
\text { perumahan yang wajar } \\
\text { sudah terpenuhi }\end{array}$ & 0,552 & Valid \\
\hline $\mathrm{X} 2.21$ & $\begin{array}{l}\text { saya merasa bahwwa } \\
\text { pakaian yang saya pakai } \\
\text { mexupakan hasil ierih } \\
\text { payah bekerja di } \\
\text { perusahaan ini }\end{array}$ & 0,604 & Valid \\
\hline $\mathrm{X} 2.22$ & $\begin{array}{l}\text { Atasan saya selalu } \\
\text { memberikan pujian } \\
\text { apabila saya } \\
\text { menjalankan tugas } \\
\text { pekerjaan dengan hasil } \\
\text { memuaskan }\end{array}$ & 0,589 & Valid \\
\hline $\mathrm{X} 2.23$ & $\begin{array}{l}\text { Saya selalu dilibatkan } \\
\text { dalam pertemuan atau } \\
\text { rapat dalam mengambil } \\
\text { keputusan di perusahaan }\end{array}$ & 0,653 & Valid \\
\hline $\mathrm{X} 2.24$ & $\begin{array}{l}\text { saya merasa senang bila } \\
\text { pengabdian saya selama } \\
\text { bekerja diakui oleh } \\
\text { atasan }\end{array}$ & 0,676 & Valid \\
\hline $\mathrm{X} 2.25$ & $\begin{array}{l}\text { Pekerjaan yang saya } \\
\text { lakulkan sekarang } \\
\text { membutuhkan lebih } \\
\text { banyak walktu jam kerja } \\
\text { untuk dapat diselesaikan }\end{array}$ & 0,650 & Valid \\
\hline
\end{tabular}

\begin{tabular}{|c|c|c|c|c|}
\hline & $\mathrm{X} 2.26$ & $\begin{array}{l}\text { saya bekeria lembur } \\
\text { untuk raendopatkan } \\
\text { bayaran lebih dari } \\
\text { perusahan }\end{array}$ & 0,462 & Valid \\
\hline & $\mathrm{X} 2.27$ & $\begin{array}{l}\text { Anda dapat } \\
\text { mertuelessikan 1okeriann } \\
\text { bersama teamiwark }\end{array}$ & 0,450 & Valhd \\
\hline & $\mathrm{X} 2.28$ & $\begin{array}{l}\text { Saya merasa tertantang } \\
\text { vatuk menvelesaikan } \\
\text { toges yang diberikan }\end{array}$ & 0,424 & Valid \\
\hline \multirow[t]{6}{*}{$\begin{array}{l}\text { Produktivitas } \\
\text { (I) }\end{array}$} & Y1 & $\begin{array}{l}\text { Kuantitas keria yang } \\
\text { diberiksan sestuai dengan } \\
\text { kemampuan anda }\end{array}$ & 0,534 & Valid \\
\hline & $Y_{2}$ & $\begin{array}{l}\text { Anda bersodia diberi } \\
\text { tambahan kuantitas keria } \\
\text { diloar jam kerja apabila } \\
\text { dibutuhlon }\end{array}$ & 0,722 & Valid \\
\hline & Y3 & $\begin{array}{l}\text { Anda mematuhi nocma: } \\
\text { porma yang berlakn } \\
\text { poda perumahaus }\end{array}$ & 0,645 & Valid \\
\hline & $\mathrm{Y}, 4$ & $\begin{array}{l}\text { Anda mampu bekeria } \\
\text { kevaai dengen standar } \\
\text { perusahaza }\end{array}$ & 0,721 & Valid \\
\hline & Y5 & $\begin{array}{l}\text { Anda mampu } \\
\text { meryelessikan 1ckeñan } \\
\text { tepat pada woltunya. }\end{array}$ & 0,064 & Valid \\
\hline & Y.6 & $\begin{array}{l}\text { Anda badic bekeria tepst } \\
\text { wakty. }\end{array}$ & 0,625 & Valid \\
\hline
\end{tabular}

dalam penelitian ini dinyatakan valid untuk digunakan sebagai alat ukur variabel.

\section{Tabel 2 Hasil Uji Reliabilitas}

\begin{tabular}{|l|c|c|}
\hline \multicolumn{1}{|c|}{ Variabel } & $\begin{array}{c}\text { Alpha } \\
\text { Cronbrach }\end{array}$ & Keterangan \\
\hline Stres (X1) & 0.851 & Reliable \\
\hline Motivasi (X2) & 0.936 & Reliable \\
\hline $\begin{array}{l}\text { Produktivitas } \\
\text { (Y) }\end{array}$ & 0.721 & Reliable \\
\hline
\end{tabular}

Semua variabel memiliki nilai alphaCronbach lebih besar dari 0,60, jadi dapat disimpulkan bahwa semua variabel yang digunakan dalam penelitian ini adalah reliabel.

\section{Uji Normalitas}

\section{Tabel 3 Hasil Uji Normalitas}

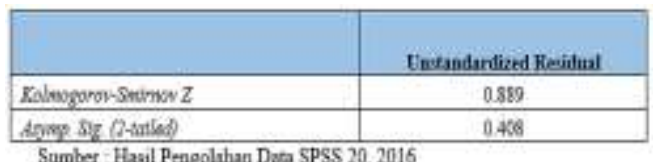

Besarnya nilai kolmogorov-smirnov adalah 0,889 dan nilai signifikansinya 0,408 . Nilai signifikansi tersebut lebih besar dari 0,1 , jadi dapat disimpulkan bahwa data residual berdistribusi normal.

\section{Uji Multikolinieritas}

\section{Tabel 4 Uji Multikolineritas}

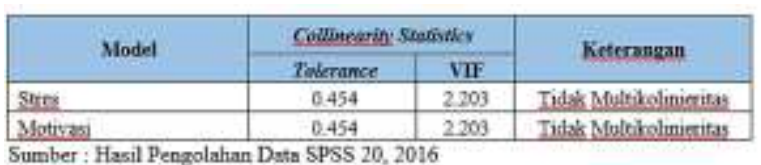

Setiap variabel mempunyai nilai tolerance $>$ 0,10 dan nilai VIF $<10$, sehingga dapat disimpulkan bahwa tidak terjadi multikolinieritas antara variabel bebas dalam model regresi ini.

Diketahui bahwa masing-masing indikator pertanyaan yang digunakan mempunyai nilai $\mathrm{r}$ hitung yang lebih besar dari 0,1654 $\mathrm{r}$ tabel, yang berarti indikator pertanyaan dari masing-masing variabel yang digunakan 


\section{Uji Heteroskedastisitas}

Table 5 Uji Heteroskedatisitas

\begin{tabular}{|l|l|c|}
\hline No & \multicolumn{1}{|c|}{ Variabe-1 } & Sag \\
\hline 1 & Stres & 0.985 \\
\hline 2 & Motivas & 0.852 \\
\hline
\end{tabular}

Diketahui bahwa nilai signifikasi variabel Stres $\left(\mathrm{X}_{1}\right)$ sebesar 0,985 lebih besar dari 0,1 yang artinya tidak terjadi heteroskedastisitas. Variabel Motivasi $\left(\mathrm{X}_{2}\right)$ sebesar 0,852 lebih besar dari 0,1 yang artinya tidak terjadi heteroskedastisitas. Jadi dapat disimpulkan bahwa model regresi $\mathrm{X}_{1}, \mathrm{X} 2$ dan $\mathrm{Y}$ tidak mengandung heteroskedastisitas.

\section{Uji Analisis Regresi Berganda}

\section{Tabel 6 Hasil Uji Regresi}

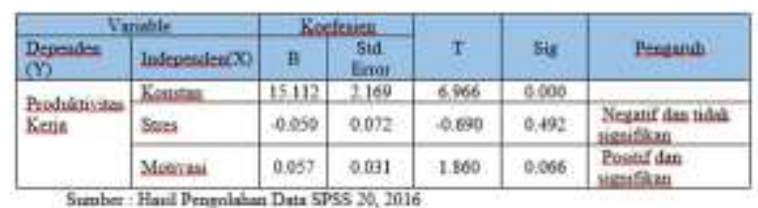

Dikarenakan hasil dari salah satu dari variabel negatif dan tidak signifikan maka penulis melakukan Trimming atau pengujian kedua untuk menghitung variabel yang signifikan saja dengan hasil perhitungan sebagai berikut :

Tabel 7 Hasil Uji Regresi Setelah

\section{Trimming}

\begin{tabular}{|c|c|c|c|c|c|c|}
\hline \multicolumn{2}{|c|}{ Varible } & \multicolumn{2}{|c|}{ Kodesias } & \multirow[b]{2}{*}{ I } & \multirow[b]{2}{*}{ Sig } & \multirow[b]{2}{*}{ Pengal } \\
\hline $\begin{array}{l}\text { Dependen } \\
(Y)\end{array}$ & Itudevendas 00 & B & Sid & & & \\
\hline \multirow{2}{*}{$\begin{array}{l}\text { Brodubiontas } \\
\text { Rejal }\end{array}$} & Bosotan & 14.431 & 1.928 & 7.487 & 0.000 & \\
\hline & Mativasi & 0.042 & 0.021 & 2010 & 0.047 & $\begin{array}{l}\text { Positif des } \\
\text { sigrifikan }\end{array}$ \\
\hline
\end{tabular}

Koefisien regresi variabel motivasi mempunyai arah positif dalam pengaruhnya terhadap produktivitas kerja. Hasil perhitungan Dari hasil koefisien regresi berganda yang telah dijelaskan pada uraian diatas selanjutnya akan dilakukan pengujian hipotesis yang dilakukan secara parsial maupun simultan.

\section{Uji F}

\section{Tabel 7 Uji F}

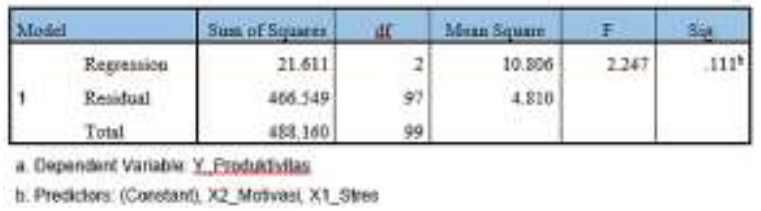

Tabel 7 Uji F Setelah Trimming

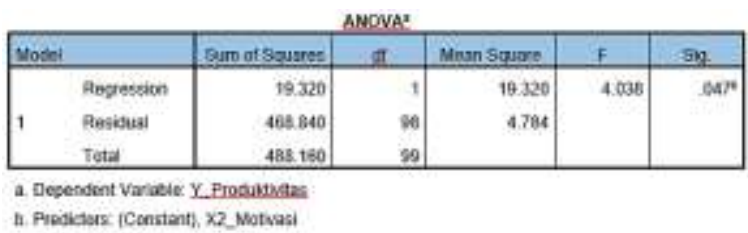

\section{Pembahasan}

\section{Pengaruh Stres Terhadap Produktivitas}

Berdasarkan hasil uji statistik yang telah dijelaskan menunjukkan bahwa H1 ditolak, yang berarti tidak terdapat pengaruh positif dan signifikan antara stres terhadap produktivitas kerja. Hasil ini menunjukkan bahwa stres kerja tidak mempengaruhi produktivitas kerja karyawan di PT Epson Batam. Hal ini mendukung penelitian Dwi Septianto (2010) yang memberikan pemahaman pada penelitiannya bahwa stres kerja memiliki pengaruh negatif dan tidak signifikan.

\section{Pengaruh Motivasi Terhadap Produktivitas Kerja}

Berdasarkan hasil uji statistik yang telah dijelaskan menunjukkan bahwa H2 diterima, yang berarti dapat ditunjukkan bahwa motivasi memang mempunyai pengaruh positif dan signifikan pada produktivitas kerja. Hal ini menunjukan bahwa karyawan akan lebih produktif dalam melakukan pekerjaan jika dimotivasi oleh sesuatu. Hal ini sesuai dengan penelitian Ibriati Kartika Alimuddin (2012) yang mana motivasi kerja berpengaruh 
positif dan signifikan terhadap produktivitas kerja.

\section{Pengaruh Stres dan Motivasi Terhadap Produktivitas Kerja}

Berdasarkan hasil uji yang telah dijelaskan di atas, menunjukkan bahwa $\mathrm{H} 3$ diterima, dimana terdapat pengaruh positif dan signifikan antara stres dan motivasi terhadap produktivitas kerja. Hal ini menunjukkan bahwa stres dan motivasi mempengaruhi produktivitas kerja. Hal ini sesuai dengan penilitian Miftah Chareti Rahmah (2013) dimana Stres dan Motivasi berpengaruh terhadap kinerja karyawan.

\section{KESIMPULAN dan SARAN}

\section{a. Kesimpulan}

Berdasarkan pada hasil penelitian, maka kesimpulan dari penelitian ini adalah sebagai berikut:

1. Hasil penelitian menunjukkan adanya pengaruh yang positif dan tidak signifikan antara stres terhadap produktivitas karyawan yang ada pada PT Epson Batam. Hal ini menunjukkan bahwa tidak adanya pengaruh yang positif dan signifikan antara variabel stress terhadapa produktivitas karyawan. Dan hipotesis pertama yang menyatakan bahwa adanya pengaruh stres terhadap produktivitas kerja ternyata tidak memilik pengaruh di PT Epson Batam. Dimana stres kerja tidak memiliki dampak terhadap produktivitas kerja karyawan dan produktivitas kerja berjalan degan lancar meskipun karyawan sedang mengalami stres.

2. Hasil penelitian menunjukkan bahwa adanya pengaruh yang positif dan signifikan antara motivasi terhadap produktivitas kerja yang ada pada PT Epson Batam. Hal ini menunjukkan bahwa adanya pengaruh yang positif dan signifikan antara variabel motivasi terhadap variabel produktivitas kerja. Dan hipotesis kedua yang menyatakan bahwa adanya pengaruh motivasi terhadap produktivitas kerja karyawan yang terbukti kebenarannya yang dilihat dari motivasi yang ada di PT Epson Batam pada karyawan bagian HR berjalan dengan sangat baik.

3. Hasil penelitian menunjukkan bahwa adanya pengaruh yang positif tetapi tidak signifikan antara stres dan motivasi terhadap produktivitas kerja yang ada pada PT Epson Batam. Bisa dikatakan secara bersama-sama (parsial) variabel stres dan motivasi berpengaruh yang positif tetapi tidak signifikan terhadap Produktivitas Kerja. Hal ini dapat disimpulkan jika stres tidak berpengaruh sama sekali terhadap produktivitas kerja karyawan di PT Epson batam tetapi motivasi sangat berpengaruh terhadap produktivitas kerja yang ada di PT Epson batam.

\section{b. Saran}

Berdasarkan kesimpulan yang diperoleh dalam penelitian ini, maka diajukan saransaran sebagai pelengkap terhadap stres dan motivasi yang ada di PT Epson Batam sebagai berikut :

1. Pada hasil kuesioner penelitian yang terdapat butir-butir pertanyaan pada variabel stres (X1) menunjukkan, bahwa variabel ini mendapat respon yang positif dan juga terdapat pertanyaan yang belum mencapai nilai positif pada karyawan yang bekerja dibagian GO (General Office). Butir-butir pernyataan tersebut tidak berpengaruh dan berkaitan dengan variabel stres (X1) 
ini terhadap produktivitas kerja karyawan General Office.

2. Pada hasil kuesioner yang terdapat pada variabel motivasi (X2) menunjukkan beberapa butir pertanyaan tersebut menunjukkan hasil yang positif. Hal ini menunjukan motivasi sangat dibutuhkan di PT Epson Batam untuk dapat meningkatkan produktivitas kerja yang berlangsung. Motivasi juga sangat berpengaruh terhadap produktivitas kerja karyawan pada bagian General Office. Sehingga sebaiknya PT Epson Batam semakin meningkatkan kegiatan yang memacu motivasi karyawan agar produktivitas kerja semakin meningkat.

3. Penelitian ini diharapkan mampu memberikan kontribusi kepada perusahaan agar memperhatikan karyawan lebih baik lagi dari segi stress kerja dan motivasi kerja yang dialami oleh karyawan.

\section{DAFTAR PUSTAKA}

Agustina. (2014). Pengaruh Motivasi Terhadap Produktivitas Kerja Karyawan Pada PT. Dwimitra Palma Lestari Samarinda. eJournal Administrasi Bisnis, 401-415.

Alimuddin, I. K. (2012). Pengaruh Motivasi Terhadap Produktivitas Kerja Karyawan Pada PT. Telkom Indonesia, Tbk Cabang Makassar. Unhas.ac.id.

Anoraga, P. (2001). Psikologi Kerja. Jakarta: PT. Rineka Cipta.

Badeni. (2013). Kepemimpinan \& Perilaku Organisasi. Bandung: Alfabeta.
Chukawa, Edwin Maduka and Obiefuna Okafor. (August 2014). Effect of Motivation on Employee Productivity: A Study of Manufacturing Companies in Nnewi. International Journal of Managerial Studies and Research, 2(7), 137-147.

Ghozali, I. (2006). Aplikasi Multivariate dengan Program SPSS. Semarang: Badan Penerbit Universitas Diponegoro.

Guay et al, F. (2010). Intrinsic, identified, and controlled types. British Journal of Educational Psychology.

Hasibuan, M. S. (2006). Manajemen Dasar, Pengertian dan Masalah. (E. Revisi, Red.) Jakarta: Bumi Aksara.

Hermawan, A. (2009). Penelitian Bisnis. Jakarta: PT. Grasindo.

Rahmah, C. M. (2013). Pengaruh Stres dan Motivasi Kerja Terhadap Kinerja Staf Keuangan di Pemerintah Kota Makassar. Unhas.ac.id.

Septianto, D. (2010). Pengaruh Lingkungan Kerja dan Stres Kerja Terhadap Kinerja Karyawan Studi Pada PT. Patay Raya Semarang. Undip.ac.id.

Simamora, H. (2004). Manajemen Sumber Daya Manusia (ke 3 uppl.). Yogyakarta: STIE YKPN.

Sopiah. (2008). Perilaku Organisasi. Yogyakarta: CV. Andi Offset.

Sugiyono. (2008). Metode Penelitian Bisnis( Pendekatan Kuantitatif, Kualitatif 
dan R\&D) (Cetakan ke sebelas uppl.). Bandung: Alfabeta.

Uno, H. B. (2009). Teori Motivasi \& Pengukurannya. Jakarta: Bumi Aksara.

Yuniarsih, P. D. (2009). Manajemen Sumber Daya Manusia. Bandung: Alfabeta. 